Ivana M. Marinković *

https://doi.org/10.18485/analiff.2020.32.1.13

Western Serbia Academy of Applied Studies, College of Applied Sciences Užice

\section{Dragana D. Pešić}

University of Kragujevac,

Faculty of Hotel Management and Tourism in Vrnjačka Banja
378.147:811.111

Originalni naučni rad

Prihvaćen: 24.06.2020.
Primljen: 12.03.2020.

\title{
THE IMPORTANCE OF LANGUAGE LEARNING STRATEGIES IN FOREIGN LANGUAGE ACQUISITION
}

The paper reports the results of a study on language learning strategy preferences of higher-education students. It is motivated by an ever lower level of English proficiency although most of students have been studying English since the first grade of primary education. The translated version of the SILL questionnaire was used (Oxford, 1990), with several personal background questions added for the purpose of clarifying the results. The data were analysed using the SPSS software. The results show either low or medium strategy utilisation per category, social strategies being most frequently used, followed by compensation, metacognitive and cognitive ones, whereas affective and memory strategies were the least favoured. Average and high-proficiency students use a vast majority of strategies more often than low-proficiency ones. However, affective and memory strategies are most often employed by the least successful students. The comparison between male and female students' strategy utilisation shows that the former use four categories of strategies more often than the latter, who are more frequent users of social strategies only. However, T-test results reveal statistically significant gender differences in the use of only several individual strategies. The above-mentioned, together with the fact that more than half of the students belong to the low-proficiency group, indicates that the explicit strategy instruction would be beneficial to their English language acquisition.

Keywords: language learning strategies, English proficiency, higher education, strategy preferences, strategy instruction

* Contact address: Ivana Marinković, Western Serbia Academy of Applied Studies, College of Applied Sciences Užice, Trg Svetog Save 34, 31000 Užice, Serbia; ivana.marinkovic@vpts.edu.rs 


\section{INTRODUCTION}

In today's global world, foreign language proficiency and computer literacy have a significant advantage over other skills and knowledge, and represent an invaluable asset and a gate to a wide range of employment opportunities worldwide. An analysis of job advertisements posted on a Serbian employment website shows that university graduates are expected to have achieved at least B2 English proficiency level (Marinković and Pešić, 2018). Therefore, being an expert in a specific field will hardly increase one's employability unless it is accompanied by their fluency in English.

The Serbian Ministry of Education, Science and Technological Development of the Republic of Serbia has followed this hint and introduced English as a compulsory subject from the first grade of primary education. Pursuant to the regulations on the curricula of joint subjects in vocational and art schools, the expected level of English proficiency by the end of secondary vocational education is B2 (Правилник о изменама иравилника о йлану и ироіраму образовања и васиитағьа за зајеуничке сииручне ирредмейе у стиручним и умейничким школама, 2015).

However, according to English teachers employed with Serbian faculties awarding degrees in science and engineering, most of the freshmen are at A1 level, and only a fifth of them manage to reach the level required by employers, whereas as many as one third of the students either fail to move above A1 or reach only A2 level (Pešić and Marinković, 2018). Despite the fact that English is still in the shadow of vocation-specific courses, and very often an elective course at faculties, such a situation is both surprising and disappointing, and calls for an instant reaction and changes in both teachers' and students' attitudes towards English language teaching and learning.

The above-mentioned problems served as the inspiration for the research presented in this paper. It draws upon ample literature stressing the importance of language learning strategies (LLS) as a useful means of improving foreign language proficiency, and one of few factors that can be taught and therefore should be embedded in the language learning curriculum. The aim of the research is to identify language strategy preferences of a group of college students, to find out if they are affected by gender differences, as well as to what extent they affect the students' English proficiency. 


\section{LITERATURE REVIEW}

LLS are techniques that learners consciously use in order to improve their progress in acquiring, storing, retaining and using information in the second or foreign language (Oxford, 1990: 166).

An impressive number of studies have been carried out since the 1990s in a wide variety of learning contexts, most often employing the Strategy Inventory for Language Learning, developed by Rebecca Oxford in 1990 to serve as a standardised instrument that would ensure the collection of comparable data.

The results obtained using the SILL questionnaire have often been contradictory, provoking severe criticism on grounds of its reliability (Dörnyei, 2005). However, due to its easily comprehensible structure and adaptability to different educational and cultural contexts, it has managed to remain the most popular data collection method in the realm of LLS (Amerstofer, 2018). If combined with a qualitative research method or some qualitative personal background questions, it can provide quite helpful information, relevant, at least, to a specific learning context.

The attempts to link self-reported strategy use with learner variables such as gender and proficiency levels have been an important part of a huge number of studies (Chamot, 2004). As for gender as a factor affecting the choice of LLS, most studies have found that female students use a greater number of strategies more frequently than their male counterparts (Green and Oxford,1995), but there are also those that have found no differences between female and male students regarding their strategy use (Vandergrift, 1997).

Proficiency has often been found to be directly influenced by the use of LLS, primarily by those requiring the active use of a foreign language (Green and Oxford, 1995). Good language learners have been found to be autonomous learners, fully aware of their own learning processes, and oriented towards the communicative aspect of language learning (Wong and Nunan, 2011).

Such conclusions have given rise to the research into the efficiency of strategy instruction in the language classroom. The results have indicated that students highly benefit from the explicit strategy instruction embedded in the regular course work as it boosts their motivation and self-efficacy, and facilitates better overall achievement (Mizumoto and Takeuchi, 2009; Nunan, 1997; Sarafianou and Gavriilidou, 2015). 


\section{METHODOLOGY}

\section{PARTICIPANTS}

The research discussed in this paper involved 57 second-year students enrolled at a college of vocational studies, 20 males and 37 females. They come from different educational backgrounds as they completed different secondary schools in different towns in Serbia. Their English language proficiency is reflected by the grades they achieved at the end of the first year at the college. Based on these grades, they are divided into 3 groups: low proficiency (grades 6 and 7), average proficiency (grade 8), and high proficiency students (grades 9 and 10).

\section{INSTRUMENT}

The participants completed a questionnaire comprising two parts. The first part included 6 personal background questions, which required information on students' gender, the grade in which they started learning English, the grade they achieved at the end of the first year of their studies at the college, the language skill they were the most successful at, the language skill they found the hardest to develop, and how often they studied English at home. The second part was the translated version of the standardised SILL questionnaire (Oxford, 1990), comprising 50 strategy statements divided into 6 categories: memory, cognitive, metacognitive, compensation, affective and social strategies. The participants expressed their attitudes to strategy utilisation by marking one of the items on a five-point Likert scale, ranging from always/almost always to never/ almost never. Oxford's (1990) key to understanding the mean scores of the SILL questionnaire was used. It defines average means of 1.0 to 2.4 as low strategy use, 2.5-3.4 as medium, and 3.5-5.0 as high strategy use. The purpose of the first part of the questionnaire was to shed light on potentially confusing results of the SILL questionnaire and add some qualitative value to the quantitative nature of this questionnaire.

The collected data were processed using the SPSS software. The independent-samples t-test was used to determine whether the research participants' strategy preferences differ based on gender. Descriptive statistics was used to calculate the mean values of different variables, and the one-way analysis of variance (ANOVA) was used to determine whether 
THE IMPORTANCE OF LANGUAGE LEARNING STRATEGIES IN ...

there are any statistically significant differences between the students of different English proficiency levels regarding their strategy preferences.

\section{RESULTS AND DISCUSSION}

\section{PERSONAL BACKGROUND QUESTIONNAIRE}

The total number of participants involved 20 males (35.1\%) and 37 females $(64.9 \%)$. By the time of the research, the participants had been studying English for at least 9 years $(18.9 \%)$, whereas most of them, i.e. $66.7 \%$ had been studying it for 13 years. The remaining participants had spent either 11 or 12 years studying English before they enrolled at the college. Taking into consideration such a long period of studying this foreign language, their grades at the end of the first year of studies appeared to be far lower than expected (Table 1).

\begin{tabular}{|c|c|c|c|c|}
\hline Grade & Frequency & Percent & Valid Percent & Cumulative Percent \\
\hline 6 & 16 & 28.1 & 29.6 & 29.6 \\
\hline 7 & 15 & 26.3 & 27.8 & 57.4 \\
\hline 8 & 11 & 19.3 & 20.4 & 77.8 \\
\hline 9 & 5 & 8.8 & 9.2 & 87.0 \\
\hline 10 & 7 & 12.3 & 13.0 & 100.0 \\
\hline Total & 54 & 94.7 & 100.0 & \\
\hline No answer & 3 & 5.3 & & \\
\hline \multicolumn{6}{|c|}{57} & 100.0 & & \\
\hline
\end{tabular}

Table 1: Participants' grades at the end of the first year of studies

A majority of the participants (57.4\%) achieved grades 6 or 7 , which reflect a low level of proficiency in this specific context. A high percentage of them $(20.4 \%)$ were at an average proficiency level, whereas the percentage of those who managed to achieve grades 9 or 10 was $9.2 \%$ and $13.0 \%$, respectively.

As for the main language skills, more than a third of the students (38.9\%) found speaking the most difficult skill to develop. It was followed by listening $(29.6 \%)$ and writing $(27.8 \%)$, whereas reading was reportedly 
the easiest skill (3.7\%), which complies with their answers to the question about the language skill they were the most successful at. Namely, a majority of students $(39.3 \%)$ reported being the most successful at reading in English, $33.9 \%$ at listening; only $16.1 \%$ of students reported being successful at speaking in English, whereas the percentage of those good at writing in English was much lower (10.7\%). These facts clearly show that the research participants are far more successful at receptive skills than in productive ones.

The last question in this part of the questionnaire was about how often they studied English at home, and it elicited quite surprising answers. Much more than half of the students reported studying English only before tests $(63.6 \%)$ or never $(7.3 \%)$, finding what they learnt in the classroom sufficient. Taking into account the fact that English is a one-semester course in the first and second year of studies at this college, and that there are only 2 pre-exam tests per semester, the results are quite disappointing, too. The percentage of those who studied English only before classes, i.e. once a week, was $12.7 \%$, and only $16.4 \%$ of the research participants reported learning some English on a daily basis (Table 2).

\begin{tabular}{|l|c|c|c|c|}
\hline & Frequency & Percent & $\begin{array}{c}\text { Valid } \\
\text { Percent }\end{array}$ & $\begin{array}{c}\text { Cumulative } \\
\text { Percent }\end{array}$ \\
\hline Almost every day & 9 & 15.8 & 16.4 & 16.4 \\
\hline Only before classes & 7 & 12.3 & 12.7 & 29.1 \\
\hline Only before tests & 35 & 61.4 & 63.6 & 92.7 \\
\hline $\begin{array}{l}\text { Never, learning during } \\
\text { classes is enough for me }\end{array}$ & 4 & 7.0 & 7.3 & 100.00 \\
\hline $\begin{array}{l}\text { Number of students who } \\
\text { answered the question }\end{array}$ & 55 & 96.5 & 100.0 & \\
\hline No answer & 2 & 3.5 & & \\
\hline Total number of students & 57 & 100.0 & & \\
\hline
\end{tabular}

Table 2: Frequency of studying English at home 
The results of the first part of the questionnaire call for an instant reaction and further research into the reasons for such low achievement and, in general, surprisingly poor motivation of tertiary-level students to master English despite the fact that English proficiency would significantly improve their future employment prospects.

To this end, thorough research into the nature of the English language instruction at both primary and secondary level of education is necessary, with special emphasis on the teaching methodology and teachers' expectations for language learners.

However, language teachers must not be held entirely responsible for such discouraging results. Educational authorities should recognise the mismatch between the significance they attach to the knowledge of English and the space allocated to this course in the curricula as the burning issue. The former is reflected in the expected outcomes, the latter in the fact that students have only two English classes a week in primary and secondary schools, and that English is still an elective course at a great number of higher education institutions. The whole matter is further complicated by the fact that foreign languages are expected to be taught effectively in large groups of mixed-ability students.

Therefore, the responses about core language skills seem to be a logical consequence of such reality, which is far from convenient and stimulating for the development of fluency in a foreign language as it is impossible to devote enough attention to individual students.

\section{SILL QUESTIONNAIRE}

One of the aims of this research was to find out if there are any significant differences between male and female students regarding the frequency of use of LLS. The collected data were analysed using an independent-samples t-test, which revealed that males use memory, compensation, metacognitive and affective strategies more frequently than females, the latter being more frequent users of social strategies only. Females' preferences for social strategies have also been reported by many other researchers (Ehrman and Oxford, 1989; Politzer, 1983). As to cognitive strategies, the same mean frequency of use (2.90) was reported by both males and females (Table 3 ). 
Ивана М. Маринковић, Драгана Д. Пешић

\begin{tabular}{|c|c|c|}
\hline \multirow{2}{*}{ Strategy category } & \multicolumn{2}{|c|}{ Mean frequency of strategy use } \\
\cline { 2 - 3 } & Male & Female \\
\hline Memory & 2.60 & 2.35 \\
\hline Cognitive & 2.90 & 2.90 \\
\hline Compensation & 3.16 & 3.08 \\
\hline Metacognitive & 3.09 & 3.07 \\
\hline Affective & 2.58 & 2.42 \\
\hline Social & 3.00 & 3.31 \\
\hline
\end{tabular}

Table 3: Mean frequencies of strategy use by male and female students

However, according to the statistical analysis of the collected data, the above-mentioned differences in the use of different strategy categories by male and female students are not considered statistically significant $(p<0.05$ being the statistical significance cutoff value). Statistically significant results were obtained for only several individual strategies, as shown in Table 4.

\begin{tabular}{|l|c|c|c|c|}
\hline \multicolumn{1}{|c|}{ SILL statement } & \multirow{2}{*}{$\begin{array}{c}\text { Strategy } \\
\text { category }\end{array}$} & $\begin{array}{c}\text { Sig. } \\
\text { (2-tailed) }\end{array}$ & male & female \\
\cline { 4 - 5 } & & & & Mean \\
\hline $\begin{array}{l}\text { A3. I connect the sound of a new } \\
\text { Ef word and an image or picture } \\
\text { it. }\end{array}$ & Memord to help me memorise & 0.041 & 3.05 & 2.36 \\
\hline $\begin{array}{l}\text { A7. I physically act out new EL } \\
\text { words. }\end{array}$ & Memory & 0.039 & 2.00 & 1.42 \\
\hline $\begin{array}{l}\text { B22. I try not to translate word } \\
\text { for word. }\end{array}$ & Cognitive & 0.034 & 3.16 & 3.83 \\
\hline $\begin{array}{l}\text { E43. I write down my feelings in } \\
\text { a language learning diary. }\end{array}$ & Affective & 0.001 & 2.15 & 1.22 \\
\hline
\end{tabular}


THE IMPORTANCE OF LANGUAGE LEARNING STRATEGIES IN ...

\begin{tabular}{|l|c|c|c|c|}
\hline $\begin{array}{l}\text { F45. If I do not understand } \\
\text { something in EL, I ask the other } \\
\text { person to slow down or say it } \\
\text { again. }\end{array}$ & Social & 0.019 & 3.05 & 3.75 \\
\hline $\begin{array}{l}\text { F48. I ask for help from EL } \\
\text { speakers. }\end{array}$ & Social & 0.002 & 2.94 & 3.86 \\
\hline
\end{tabular}

Table 4: LLS significantly affected by gender differences

Females use all social strategies except one (F49: I ask questions in $E L)$ more frequently than their male peers, though statistically significant differences can be noted only with two of these strategies - asking the other people to slow down or repeat the confusing words $(\mathrm{p}=0.019)$, and asking help from EL speakers ( $\mathrm{p}=0.002)$.

As can be observed from Table 4, one more strategy, belonging to the cognitive category, was used to a statistically significant degree more frequently by females $(\mathrm{p}=0.034)$. The remaining three strategies shown in Table 4 were more frequently used by males, though their mean frequency of use was either low (A7. I physically act out new EL words, and E43. I write down my feelings in a language learning diary) or moderate (A3. I connect the sound of a new EL word and an image or picture of the word to help me remember it).

As for the remaining forty-four strategies, the results indicate that there are no statistically significant differences between male and female students regarding the choice and frequency of use of these strategies. The differences between mean frequencies of use of these strategies are therefore more likely due to chance than to gender differences. These results are consistent with the findings of some other researchers, such as Vandergrift (1997), and although they cannot be generalised, they can be helpful in the given context as they indicate that both males and females would benefit from the same teaching materials and methods.

Another aim of the research was to find out about respondents' strategy preferences for the purpose of getting to know their way of learning better, and see if the insufficient or inadequate strategy utilisation could be a reason of their poor overall achievement. The results show that the overall frequency of language learning strategy utilisation by these 
students is moderate, i.e. 2.86 (Table 5). Indirect strategies are more frequently employed than direct ones. An interesting finding is that they most frequently use social strategies. These are followed by compensation, metacognitive, and cognitive strategies, whereas affective and memory strategies are the least frequently used, their mean frequency values being 2.49 and 2.45 , respectively.

\begin{tabular}{|l|c|c|}
\hline \multicolumn{1}{|c|}{ Strategy category } & Mean frequency of use & Level of use \\
\hline Social & 3.21 & Moderate \\
\hline Compensation & 3.12 & Moderate \\
\hline Metacognitive & 3.09 & Moderate \\
\hline Cognitive & 2.90 & Moderate \\
\hline Affective & 2.49 & Low \\
\hline Memory & 2.45 & Low \\
\hline Overall mean & 2.86 & Moderate \\
\hline
\end{tabular}

Table 5: Mean frequency of use of LLS

Students' replies to the question about how often they learn English shed some light on these results. Most of the students involved in this research try to learn English through social interaction and by drawing on their background knowledge. They avoid direct manipulation and transformation of learning materials, and their opportunities for doing it are limited, given the fact that they almost never study English outside the classroom.

This is further supported by the nature of the most frequently used individual strategies. The respondents reported a high frequency of use of only seven strategies (Table 6). 
THE IMPORTANCE OF LANGUAGE LEARNING STRATEGIES IN ...

\begin{tabular}{|l|l|c|}
\hline \multicolumn{1}{|c|}{ Category } & \multicolumn{1}{|c|}{ SILL statement } & Mean \\
\hline Memory & $\begin{array}{l}\text { A1: I think of relationships between what I } \\
\text { already know and new things I learn in English. }\end{array}$ & 3.56 \\
\hline Cognitive & B22: I try not to translate word-for-word. & 3.63 \\
\hline Compensation & $\begin{array}{l}\text { C24: To understand unfamiliar English words, } \\
\text { I make guesses. }\end{array}$ & 3.67 \\
\hline Metacognitive & $\begin{array}{l}\text { D32: I pay attention when someone is } \\
\text { speaking English. }\end{array}$ & 3.93 \\
\hline Metacognitive & $\begin{array}{l}\text { D33: I try to find out how to be a better } \\
\text { learner of English. }\end{array}$ & 3.59 \\
\hline Social & $\begin{array}{l}\text { F45: If I do not understand something in } \\
\text { English, I ask the other person to slow down } \\
\text { or say it again. }\end{array}$ & 3.51 \\
\hline Social & \begin{tabular}{l} 
F48: I ask for help from English speakers. \\
\hline
\end{tabular} & 3.57 \\
\hline
\end{tabular}

Table 6: LLS with high mean frequency of use

As for the remaining strategies, it seems that the students are either insufficiently aware of their existence, or fail to use them effectively. Therefore, the LLS instruction would definitely not be a waste of time in this particular learning context.

The last question the research attempted to answer is whether there is any correlation between the use of LLS and the respondents' English proficiency levels. The results presented in Table 7 below show that average-proficiency students (those with grade 8) use LLS most frequently (the mean frequency $=3.03$ ). They are followed by high-proficiency students (the mean frequency $=2.99$ ) and low-proficiency ones (the mean frequency $=2.75$ ). The latter use affective strategies more often than their more successful peers, though insufficiently enough. 
Ивана М. Маринковић, Драгана Д. Пешић

\begin{tabular}{|l|c|c|c|}
\hline \multirow{2}{*}{ Strategy category } & \multicolumn{3}{|c|}{ Proficiency level } \\
\cline { 2 - 4 } & $\begin{array}{c}\text { Low } \\
\text { (grades 6, 7) }\end{array}$ & $\begin{array}{c}\text { Average } \\
\text { (grade 8) }\end{array}$ & $\begin{array}{c}\text { High } \\
\text { (grades 9, 10) }\end{array}$ \\
\hline Memory & 2.43 & 2.49 & 2.42 \\
\hline Cognitive & 2.72 & 3.05 & 3.30 \\
\hline Compensation & 2.91 & 3.42 & 3.44 \\
\hline Metacognitive & 2.93 & 3.30 & 3.13 \\
\hline Affective & 2.53 & 2.47 & 2.30 \\
\hline Social & 3.10 & 3.54 & 3.19 \\
\hline Overall mean & 2.75 & 3.03 & 2.99 \\
\hline
\end{tabular}

Table 7: Mean frequencies of LLS use and proficiency levels

Table 7 shows that both average and high-proficiency students use LLS much more frequently than the least successful ones. Average-proficiency students use all strategies, except affective ones, more frequently than their least successful peers, whereas high proficiency students use all strategies except memory and affective ones more often than the least successful learners. However, high-proficiency students are not the most frequent users of LLS, as would be expected based on a number of other studies (Green and Oxford, 1995; Wharton, 2000). Such a finding is consistent with those of only a few other studies (Hong-Nam and Leavell, 2006; Philips, 1991). The explanation of its possible cause lies in the fact that high-proficiency students are those who have actually learnt how to learn, i.e. their learning process has become intrinsic and therefore they use LLS automatically, without much reflection (Hong-Nam and Leavell, 2006).

Such a result is also consistent with the finding that the fact that a learner uses strategies frequently does not necessarily imply that they use them efficiently (Yilmaz, 2010). The proper selection of strategies for a particular task is what also matters. In this particular research, it is evident that advanced students use strategies more efficiently than all other students. Unlike other students, they prefer direct LLS to indirect ones, compensation and cognitive strategies being their first two 
choices. Average-proficiency students use compensation strategies to an insignificant degree less frequently than the most successful students, but their frequency of use of cognitive strategies is much lower, these being ranked fourth on both their list and that of the least successful students. These two groups of students most frequently use social strategies.

The research into the correlation between the proficiency levels and frequency of strategy utilisation, i.e. with the students' strategy preferences, further reveals that, in addition to the above-mentioned core strategies, the most proficient students reported highly frequent use of 6 more strategies, as shown in Table 8.

\begin{tabular}{|l|l|c|}
\hline \multicolumn{1}{|c|}{ Category } & \multicolumn{1}{|c|}{ SILL statement } & Mean \\
\hline Cognitive & $\begin{array}{l}\text { B10: I say or write new English words } \\
\text { several times. }\end{array}$ & 3.54 \\
\hline Cognitive & $\begin{array}{l}\text { B15: I watch TV shows spoken in English or } \\
\text { go to movies spoken in English. }\end{array}$ & 4.57 \\
\hline Cognitive & $\begin{array}{l}\text { B18: I first skim an English passage then go } \\
\text { back and read carefully. }\end{array}$ & 4.30 \\
\hline Cognitive & $\begin{array}{l}\text { C29: If I cannot think of an English word, I use } \\
\text { a word or phrase that means the same thing. }\end{array}$ & 3.97 \\
\hline Compensation & $\begin{array}{l}\text { D31: I notice my English mistakes and use } \\
\text { that information to help me do better. }\end{array}$ & 3.77 \\
\hline Metacognitive & $\begin{array}{l}\text { E40: I encourage myself to speak English even } \\
\text { when I am afraid of making a mistake. }\end{array}$ & 3.44 \\
\hline
\end{tabular}

Table 8: Most frequently used LLS by high-proficiency learners

Table 8 shows that a majority of the strategies frequently used only by the most successful learners belong to the cognitive category, and require a high degree of active engagement on the part of the learner. Taking a closer look at these 6 strategies, one cannot but notice that each one is 
highly efficient and must have contributed to the high proficiency of these students.

Watching TV shows or films without subtitles is the most favoured strategy by these learners, and might be said to show that they have managed to develop the language learner autonomy and take responsibility for their own success as they spend their free time doing things other than those imposed by the teacher in order to improve their English proficiency.

Statistically, the results of the one-way analysis of variance (ANOVA) show significant differences between different proficiency groups in the use of 6 cognitive strategies, 3 compensation strategies, 2 metacognitive and 2 social strategies (Table 9), whereas no statistically significant differences have been determined regarding the use of memory and affective strategies. The latter can probably be ascribed to the low overall frequency of use of these two categories of strategies.

\begin{tabular}{|l|l|c|}
\hline \multicolumn{1}{|c|}{ Category } & \multicolumn{1}{|c|}{ SILL statement } & Sig. \\
\hline Cognitive & B14: I start conversations in English. & 0.019 \\
\hline Cognitive & $\begin{array}{l}\text { B15: I watch TV shows spoken in English or } \\
\text { go to movies spoken in English. }\end{array}$ & 0.000 \\
\hline Cognitive & B16: I read for pleasure in English. & 0.025 \\
\hline Cognitive & $\begin{array}{l}\text { B17: I write notes, messages, letters, or } \\
\text { reports in English. }\end{array}$ & 0.027 \\
\hline Cognitive & $\begin{array}{l}\text { B18: I first skim an English passage (read over } \\
\text { the passage quickly) then go back and read } \\
\text { carefully. }\end{array}$ & 0.000 \\
\hline Cognitive & $\begin{array}{l}\text { B19: I look for words in my own language that } \\
\text { are similar to new words in English. }\end{array}$ & 0.027 \\
\hline Compensation & $\begin{array}{l}\text { C24: To understand unfamiliar English words, } \\
\text { I make guesses. }\end{array}$ & 0.001 \\
\hline Compensation & $\begin{array}{l}\text { C28: I try to guess what other person will say } \\
\text { next in English. }\end{array}$ & 0.036 \\
\hline
\end{tabular}


THE IMPORTANCE OF LANGUAGE LEARNING STRATEGIES IN ...

\begin{tabular}{|l|l|l|}
\hline Compensation & $\begin{array}{l}\text { C29: If I cannot think of an English word, I use } \\
\text { a word or phrase that means the same thing. }\end{array}$ & 0.047 \\
\hline Metacognitive & $\begin{array}{l}\text { D32: I pay attention when someone is } \\
\text { speaking English. }\end{array}$ & 0.000 \\
\hline Metacognitive & $\begin{array}{l}\text { D38: I think about my progress in learning } \\
\text { English. }\end{array}$ & 0.001 \\
\hline Social & $\begin{array}{l}\text { F46: I ask English speakers to correct me } \\
\text { when I talk. }\end{array}$ & 0.014 \\
\hline Social & F49: I ask questions in English. & 0.007 \\
\hline
\end{tabular}

Table 9: Strategies with statistically significant differences in use among different proficiency groups of students

A closer look at the strategies listed in Table 9 reveals that they all require a solid knowledge of English, a high degree of learner autonomy and the awareness of the importance of learning it. This, together with the insufficient overall frequency of use of LLS and poor overall achievement of the research participants, suggests that more frequent utilisation of a greater number of strategies would contribute to their foreign language proficiency, as well as that they would definitely benefit from the LLS instruction during regular classes. Since most of them study English only in the classroom, the strategy instruction would maximise their language learning opportunities, thus ensuring better and longer retaining of the acquired information. This would improve weaker students' knowledge, increase their selfconfidence, and ultimately encourage them to take responsibility for their own achievement and start using the strategies favoured by independent language learners (O'Malley and Chamot, 1990). Then they would probably start spending more time studying English at home.

The core strategies reported by high-proficiency students also suggest that the insufficient proficiency might be the reason why low-proficiency students dare not tackle learning English on their own, not vice versa. This is further supported by the fact that low-proficiency students use affective 
strategies more often than their peers, which is promising as it shows that they are, at least, willing to actively engage during the classes. However, their lack of knowledge about effective learning techniques results in either sitting doing nothing or choosing inappropriate strategies in the given situation.

\section{CONCLUSION}

This study explored the use of LLS by students at a college in Serbia in order to find out whether they can be a reason for the students' low level of English proficiency.

The results show that the overall mean frequency of use of LLS by the participants is moderate (2.86), little above the lower boundary of this frequency range. Viewed per strategy category, the mean frequencies of use are either low or moderate, indicating that the participants are not fully aware of the existence of these effective means of foreign language acquisition.

The participants show a preference for social strategies, which is not a common finding in other relevant studies, but can be taken advantage of in this particular context in order to help learners improve their knowledge of English. The fact that they are willing to cooperate and empathise with others indicates that they would benefit from pair and group work activities.

The least favoured strategy categories by the respondents are affective and memory ones. Such results seem to be justified for average and advanced students, as their level of proficiency implies that they have mastered vocabulary and grammatical structures to a satisfactory level, and learnt how to manage their anxiety. However, it is completely unacceptable as far as the least successful students are concerned. Since they by far outnumber their more successful peers, the differentiation of tasks and their involvement in the activities that target memory strategies are mandatory in order to help them start making progress and acquire a sufficient knowledge base for the utilisation of a wider range of more demanding strategies.

As for average-proficiency students, they would benefit a lot from the activities and tasks which require the use of cognitive strategies.

All the above-mentioned suggests that by identifying the LLS used by a foreign language students, language teachers can get to know their 
students and the way in which they learn better, and can revise their teaching materials and design learning activities accordingly. In this particular context, gender need not be taken into account when designing the activities as gender differences seem not to affect the students' strategy utilisation significantly.

The insufficient and ineffective use of LLS by the participants can be considered as one of the causes of their poor overall achievement, which suggests that they would benefit from the explicit strategy instruction alongside the regular course work as it would raise their awareness of the existence and efficiency of various language learning techniques, and help them take the utmost advantage of language learning opportunities both in the classroom and outside it. The exposure of students to a variety of tasks and activities targeting the strategies that they need to master would make them start thinking about their own learning process, and increase their motivation to engage actively in language learning and become less dependent on the teacher. Thus, they would develop the language learner autonomy and become prepared for lifelong learning, which is one of the aims that higher education strives to achieve.

However, the strategy instruction should be introduced at the beginning levels of learning a foreign language to a degree appropriate to the age of students as it is obvious that the roots of the insufficient knowledge with which students enrol at higher education institutions lie in the previous levels of their education. Unfortunately, they are the result of an intricate web of factors, some of which are beyond the powers of both language learners and teachers.

\section{REFERENCESQWSADW}

Amerstorfer, C. M. (2018).Past its expiry date? The SILL in modern mixedmethod strategy research. Studies in Second Language Learning and Teaching, 8, 497-523. doi: 10.14746/ss1lt.2018.8.2.14

Chamot, A. U. (2004). Issues in Language Learning Strategy Research and Teaching. Electronic Journal of Foreign Language Teaching, 1(1), 14-26.

Dörnyei, Z. (2005). The Psychology of the Language Learner. Mahwah. NJ: Eribaum. 
Ehrman, M., and Oxford, R. L. (1989). Effects of Sex Differences, Career Choice and Psychological Type on Adult Language Learning Strategies. The Modern Language Journal, 73(1), 1-13.

Green, J. M., and Oxford, R. L. (1995). A Closer Look at Learning Strategies, L2 Proficiency, and Gender. TESOL Quarterly, 29(2), 261-297.

Hong-Nam, K., and Leavell, A. G. (2006). Language Learning Strategy Use of ESL Students in an Intensive English Learning Context. System, 34(3), 399-415.

Marinković, I., and Pešić, D., (2018). Good Knowledge of English as the Gateway to Knowledge without Borders. Knowledge, 22(2), 349-355.

Mizumoto, A., and Takeuchi, O. (2009). Examining the Effectiveness of Explicit Instruction of Vocabulary Learning Strategies with Japanese EFL University Students. Language Teaching Research, 13(4), 425-449. doi:10.1177/1362168809341511

Nunan, D. (1997). Does Learner Strategy Training Make a Difference. Lenguas Modernas 24, 123-142.

O'Malley, J. M., and Chamot, A. U. (1990). Learning Strategies in Second Language Acquisition. Cambridge: Cambridge University Press.

Oxford, R. L. (1990). Language Learning Strategies: What Every Teacher Should Know. Boston: Newbury House, 293-300.

Pešić, D., and Marinković, I. (2018). Teaching ESP in Vocational Schools in Serbia Today. Proceedings of IV International Conference 'Language for Specific Purposes and Professional Identity', Belgrade: Foreign Language and Literature Association of Serbia, 697-714.

Phillips, V. (1991). A Look at Learner Strategy Use and ESL Proficiency. CATESOL Journal (Nov), 57-67.

Politzer, R. (1983). An Exploratory Study of Self-reported Language Learning Behaviors and Their Relation to Achievement. Studies in Second Language Acquisition, 6, 54-65.

Правилник о изменама правилника о плану и програму образовања и васпитања за заједничке стручне предмете у стручним и уметничким школама, (2015), Службени гласник РС - Просветни гласник РС Б. 3 (2015).

Sarafianou, A., and Gavriilidou, Z., (2015). The Effect of Strategy-Based Instruction on Strategy Use by Upper-Secondary Greek Students of EFL. Electronic Journal of Foreign Language Teaching, 12(1), 21-34.

Vandergrift, L. (1997). Facilitating Second Language Listening Comprehension: Acquiring Successful Strategies. ELT Journal, Volume 53(3), 168-176. 
Wong, L. C. L., and Nunan, D. (2011). The Learning Styles and Strategies of Effective Language Learners. System, 39, 144-163. doi: 10.1016/j. system.2011.05.004

Yilmaz, C. (2010). The Relationship between Language Learning Strategies, Gender, Proficiency and Self-efficacy Beliefs: a Study of ELT Learners in Turkey. Procedia - Social and Behavioral Sciences, 2(2), 682-687.

\section{Ивана М. Маринковић Драган Д. Пешић}

\section{ЗНАЧАЈ СТРАТЕГИЈА УЧЕЊА ЈЕЗИКА У УСВАЈАЫУ СТРАНОГ ЈЕЗИКА}

\section{Сажетак}

Полазећи од општег утиска наставника енглеског језика запослених у високошколским установама да је знање овог језика код студената приликом уписа из године у годину све слабије и да мали број студената током студија направи значајан помак, спроведено је истраживање о томе које стратегије учења језика студенти користе и колико често, као и да ли у њиховом неадекватном коришћењу лежи један од разлога слабих постигнућа. Испитивање је спроведено анкетирањем студената једне високе школе струковних студија, а подаци су обрађени помоћу SPSS програма. Добијени резултати показују да испитаници ретко или умерено користе поменуте стратегије, при чему се најчешће користе друштвене, а потом компензационе, метакогнитивне, когнитивне, афективне и стратегије памћења. Доминантност индиректних стратегија у односу на директне у складу је са добијеним податком да већина студената проводи јако мало времена учећи енглески језик ван учионице. Иако мушкарци користе све категорије стратегија осим когнитивних и друштвених чешће него девојке, утицај полних разлика на избор стратегија није статистички значајан. Међутим, чињеница да успешни ученици користе когнитивне, метакогнитивне, компензационе и друштвене стратегије знатно чешће од слабијих ученика и те како потврђује да ефикасна и учестала примена адекватних стратегија доприноси успеху у учењу, а уједно и оправдава увођење учења о стратегијама учења језика у редовну наставу. Тиме би се допринело јачању аутономије ученика и њиховог самопоуздања, а самим тим и порасту мотивације за усвајањем енглеског језика као једног од предуслова за добијање већине послова, како у свету, тако и код нас.

Кључне речи: стратегије учења језика, високо образовање, енглески језик. 